\title{
Mesozooplankton carbon requirement in the Tyrrhenian Sea: its vertical distribution, diel variability and relation to particle flux
}

\author{
Roberta Minutoli*, Letterio Guglielmo \\ ULR CoNISMa, Department of Animal Biology and Marine Ecology, University of Messina, \\ Viale Ferdinando Stagno d'Alcontres 31, S. Agata, 98166 Messina, Italy
}

\begin{abstract}
Mesozooplankton consumes an important fraction of particulate organic matter sinking down the water column in all oceans. We investigated the vertical distribution (down to $2000 \mathrm{~m}$ depth) and diel variability (during a $24 \mathrm{~h}$ cycle) of the mesozooplankton carbon requirement ( $\mu \mathrm{g} \mathrm{C} \mathrm{g}^{-1} \mathrm{~d}^{-1}$ ), estimated by measuring the activity of the electron transport system (ETS), at a fixed station in the open southern Tyrrhenian Sea. To estimate the quantitative role of zooplankton in carbon losses occurring during organic particle sinking, zooplankton carbon demand was compared with organic carbon vertical flux (measured using the ${ }^{234} \mathrm{Th}:{ }^{238} \mathrm{U}$ disequilibrium method). Zooplankton abundance, biomass and community composition were also investigated, as were the vertical distribution of diel migrant species and the relative importance of crustaceans and gelatinous taxa. A distinct day-night variation of carbon demand in the upper $300 \mathrm{~m}$ of the water column was observed, with the highest values encountered during dark hours. The high values estimated in sunset samples were most likely due to the presence or dominance of the calanoid copepod Pleuromamma gracilis. Mesozooplankton were responsible for $13.2 \%$ and $8.8 \%$ of carbon losses in the meso- and bathypelagic zones, respectively. These results reflect the trophic status of the southern Tyrrhenian Sea, which is typically less oligotrophic than the central and eastern Mediterranean Sea.
\end{abstract}

KEY WORDS: Mesozooplankton · Carbon requirement - Electron transport system - Particulate organic carbon sinking flux $\cdot$ POC sinking flux $\cdot$ Tyrrhenian Sea

\section{INTRODUCTION}

The oceans play a pre-eminent role in the global carbon cycle, as they can store 50 times more $\mathrm{CO}_{2}$ than the atmosphere. Up to $98.5 \%$ of pre-industrial $\mathrm{CO}_{2}$ is in fact stored in the ocean, whereas only $1.5 \%$ is preserved in the atmosphere, because of the high solubility of $\mathrm{CO}_{2}$ (30 times higher than that of oxygen) and because of the hydrolysis reaction it undergoes to form carbonate and bicarbonate ions (Marinov \& Sarmiento 2004). Carbon cycling in the oceans is controlled mainly by 2 processes: $\mathrm{CO}_{2}$ dissolution into seawater (the so-called physical pump) and incorporation into phytoplankton biomass (the socalled biological pump). Dissolved $\mathrm{CO}_{2}$ is then transferred from the upper layers of the ocean to the sea floor by sinking currents, where it can be stored for hundreds to thousands of years. Eventually, mixing and upwelling phenomena can bring back $\mathrm{CO}_{2}$ enriched deep waters to the ocean surface.

Primary production in the relatively thin upper layer of the sea fuels the heterotrophic metabolism in the dark ocean (Burd et al. 2010). Once incorporated into phytoplankton biomass, carbon enters the planktonic grazing food web: protists and animals eat the phytoplankton, then leading up to fish and 
large marine mammals. Faeces, dead organisms and their remains (i.e. detrital particles) and prokaryotes, together with phytoplankton exudates, sink deeper into the ocean's interior, providing food to planktonic heterotrophs and, once landed on the sea floor, to the deep-sea benthos (Fabiano et al. 2001, Vanucci et al. 2001). A relatively small fraction of the sinking material is eventually buried and stored in sediments for up to millions of years (Middelburg \& Meysman 2007). Most of the reduced carbon in and below the sea floor is thus used by animals and heterotrophic prokaryotes, and returned as $\mathrm{CO}_{2}$ to the deep ocean, as part of the global carbon cycle.

Particulate organic matter (POM) cycling in the ocean's interior is controlled by the interaction of physical, chemical and biological forces (see Koppelmann et al. 2004). Approximately $90 \%$ of POM is remineralised as it sinks through the water column: heterotrophic consumption results in decreasing fluxes of organic material with increasing water depth, with the largest loss of material generally observed between 100 and $1000 \mathrm{~m}$ depth (Martin et al. 1987).

The consumption of organic particles represents the carbon demand or requirement by heterotrophs. Carbon consumed by heterotrophs in the water column is subtracted from the organic particle vertical flux, thus representing a carbon loss for the ocean's interior. Only an average $10 \%$ of POM exported from the upper photic ocean reaches the sea bottom: the remaining $90 \%$ is therefore consumed, remineralised or, once transformed into new prokaryotic biomass (through the microbial loop; Azam et al. 1983), redirected towards higher trophic levels (Berger et al. 1988, Koppelmann et al. 2000, Koppelmann \& Frost 2008).

Mesozooplankton, namely planktonic metazoans 200 to $2000 \mu \mathrm{m}$ in size, actively feed on POM (Longhurst 1991, Halsband-Lenk et al. 2003, Minutoli \& Guglielmo 2009). Diel vertical migration (DVM) of mesozooplankton is one of the most important movements of biomass in the ocean (Longhurst 1976). The active carbon transport from the ocean surface to the deep sea mediated by the mesozooplankton, hypothesised by Vinogradov (1962), reinforces the biological pump for the net transport of organic and inorganic matter through the pycnocline (Longhurst et al. 1989, 1990).

A specific and highly sensitive technique to evaluate the mesozooplankton carbon requirement from the carbon sinking flux consists of measuring the electron transport system (ETS) activity (Packard 1971, King \& Packard 1975, Owens \& King 1975, Båmstedt 1979, 1980, Bidigare et al. 1982). The ETS, nearly ubiquitous in mitochondrial membranes, can be used as an indicator of organic matter remineralisation, as it consists of a complex chain of cytochromes, flavoproteins and metabolic ions that transport electrons from catabolised foodstuffs to oxygen. The rate-limiting step of ETS is the coenzyme Q-cytochrome $b$ complex oxidation, that can be measured after the reaction of the complex with the artificial electron acceptor 2-( $p$-iodophenyl)-3( $p$-nitrophenyl)-5-phenyl tetrazolium chloride (INT) (Packard 1971). This reaction is influenced by various factors, such as temperature, salinity and sexual stage (Torres et al. 1979, Ikeda \& Fay 1981, Raymont 1983, Schalk 1988), even if adaptations to environmental conditions are possible (Anraku 1964, Musayeva \& Shushkina 1978, Båmstedt 1980, Hirche 1984). Several papers have shown a good correlation between ETS activity and in vivo respiration (Packard et al. 1974, Kenner \& Ahmed 1975, Owens \& King 1975, Devol \& Packard 1978), so that ETS activity can be used as an estimate of mesozooplankton respiration rates.

To provide new insights into the role of mesozooplankton in the carbon loss during POM sinking in open waters, we investigated the vertical distribution (down to $2000 \mathrm{~m}$ depth) and diel variability (during a $24 \mathrm{~h}$ cycle) of the mesozooplankton carbon requirement ( $\mu \mathrm{g} \mathrm{C} \mathrm{g} \mathrm{wet} \mathrm{wt}^{-1} \mathrm{~d}^{-1}$ ) at a fixed station located in the open southern Tyrrhenian Sea. To estimate the quantitative role of zooplankton in carbon losses occurring during particle sinking, the mesozooplankton carbon demand, estimated using ETS activity measurements, was related to vertical carbon fluxes, measured by the ${ }^{234} \mathrm{Th}:{ }^{238} \mathrm{U}$ disequilibrium method. Mesozooplankton abundance, biomass and community composition were also investigated, as were the vertical distribution and the relative importance of crustaceans, gelatinous taxa and vertically active migrating species.

\section{MATERIALS AND METHODS}

\section{Sampling}

Mesozooplankton was collected at a fixed station named 'VTM' in the southern Tyrrhenian Sea off Naples (39³0'00" N, 1330'00" E; 3450 m depth) during the 'TM3' oceanographic cruise on board the RV 'Universitatis', carried out from 19 to 23 April 2007 (Fig. 1). This cruise was carried out in the framework of a large national project named VECTOR (VulnErability of Coasts and marine Italian 


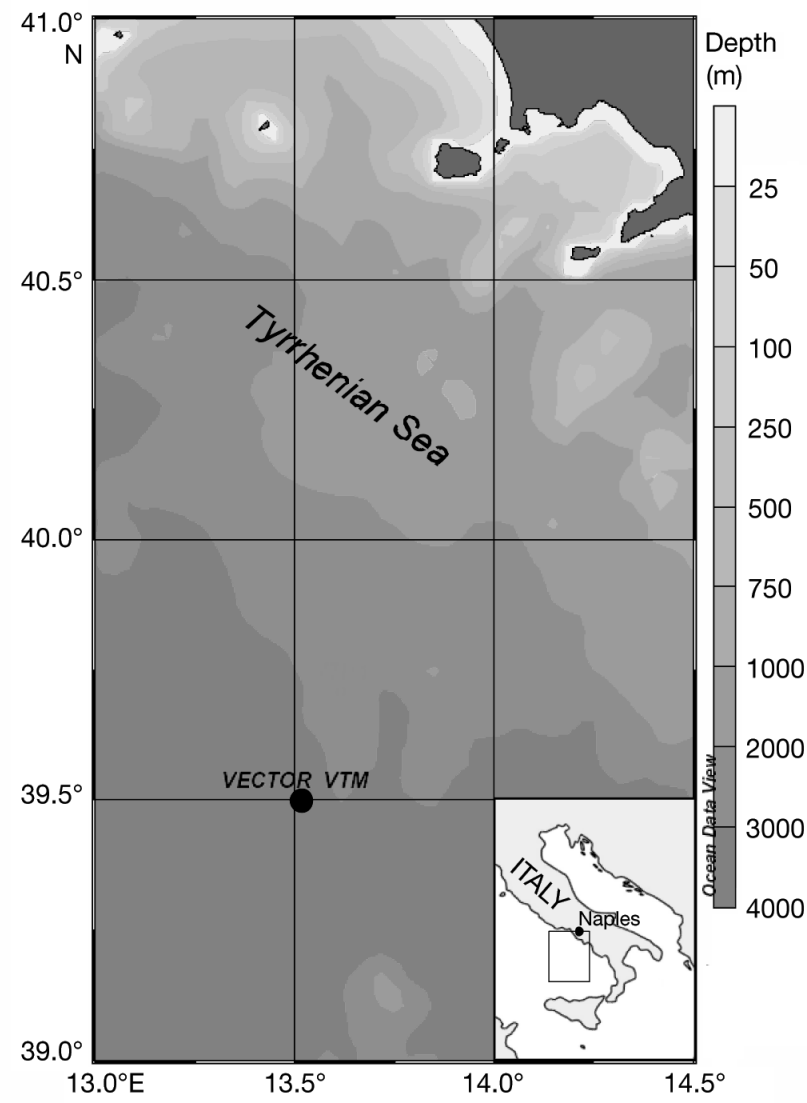

Fig. 1. Zooplankton sampling station VTM in the Tyrrhenian Sea during the 'VECTOR TM3' cruise (19-23 April 2007)

ecosystems to climaTic changes and their rOle in Mediterranean caRbon cycle) from 2006 to 2010 that included many Italian scientific operative units and investigated a large number of topics (http://vectorconisma.geo.unimib.it/). Samples were collected using the electronic multinet BIONESS (Bedford Institute of Oceanography Net and Environmental Sampling System; Sameoto et al. 1980) on 20 April 2007. The sampling instrument has a $1 \mathrm{~m}^{2}$ mouth area, with 12 horizontally arranged nets $(200 \mu \mathrm{m}$ mesh size) which can be sequentially opened and closed, and is towed at a speed of about 2 knots through a conductor cable that transmits and receives information from the vessel. Samples were collected from the surface down to $2000 \mathrm{~m}$ depth, 4 times during a $24 \mathrm{~h}$ cycle. Samplings started at 06:00 h (morning), 12:00 h (midday), 18:00 h (afternoon) and 24:00 $\mathrm{h}$ (midnight) and, at each time, took about $5 \mathrm{~h}$. The BIONESS system was equipped with a multiparametric probe Sea-Bird 911 Plus and a Seapoint fluorometer which continuously recorded temperature $(\mathrm{T})$, salinity $(\mathrm{S})$, oxygen and fluorescence. Fluorescence was measured and calculated as equiv- alent $\mu \mathrm{g} \mathrm{chl} a \mathrm{l}^{-1}$ (where chl $a$ is chlorophyll $a$ ). The conventional unit $(\mathrm{F})$ for in vivo fluorescence in the range of 0 to $5 \mathrm{~V}$ corresponds to 0 to $50 \mathrm{mg} \mathrm{m}^{-3}$ for chl $a$ with a resolution of $0.1 \mathrm{mg} \mathrm{m}^{-3}$ and an accuracy variability of $<10 \%$. Rough data of water depth (m), temperature $\left({ }^{\circ} \mathrm{C}\right)$, salinity and fluorescence were processed with ODV software to obtain vertical profiles in real time. Two flowmeters installed inside and outside the net allowed the measurement of the filtered water volume and the filtration efficiency. At each sampling time, the BIONESS was deployed vertically down to the maximum depth of $2000 \mathrm{~m}, 2$ times, for collecting mesozooplankton. During the first downcast, the physical structure of the water column, the thermocline, pycnocline and halocline depths, and the depth and thickness of the deep chlorophyll maximum (DCM) layer were analysed in order to decide upon the sampling layers. Standardised sampling intervals were 2000-1600, 1600-1400, 1400-1200, 1200-1000, 1000-800, 800-600, 600-400, 400-300, 300-200, 200-100 and 100-0 $\mathrm{m}$ for the deep haul, and $100-80,80-60,60-40,40-20$ and $20-0 \mathrm{~m}$ for the shallow haul. On board, a 21 sample from each sampling layer was split, using a Folsom splitter, into 2 separate aliquots of 11 each. A 11 aliquot was filtered on a $200 \mu \mathrm{m}$ mesh sieve, diluted in $10 \mathrm{ml}$ of seawater and immediately frozen in liquid nitrogen for subsequent analysis of the ETS. The second $1 \mathrm{l}$ aliquot was preserved in a $4 \%$ formaldehyde-seawater solution buffered with sodium tetraborate (Steedman 1976) for the subsequent taxonomic and quantitative analyses, as described below. The integrating samples $0-2000,100-0$ and $0-100 \mathrm{~m}$ from any time sampling were not used for the present study. A total of 60 frozen samples in $10 \mathrm{ml}$ of seawater and 60 preserved samples of 11 were used for the present study.

\section{Vertical carbon flux quantification}

Thorium fluxes and residence times were evaluated at $100 \mathrm{~m}$ depth by another operative unit involved in the same synoptic cruise (Dr. A. Schirone, Enea, La Spezia, Italy), assuming that thorium scavenging in this environment is mainly due to association with biogenic particles. The disequilibrium of ${ }^{234} \mathrm{Th}:{ }^{238} \mathrm{U}$ is commonly used to trace scavenging processes (Buesseler et al. 1992). ${ }^{234} \mathrm{Th}$ is a particlereactive, naturally occurring radionuclide, produced in the water column by the decay of ${ }^{238} \mathrm{U}$. After production, thorium can be scavenged onto particles and removed from the water column in association with them. The extent of the disequilibrium between ${ }^{234} \mathrm{Th}$ 
and ${ }^{238} \mathrm{U}$ is an effective tracer of scavenging processes and particle residence times in coastal waters and in the upper ocean. Due to its short half-life $(24.1 \mathrm{~d}),{ }^{234} \mathrm{Th}$ can be used to trace scavenging processes on time scales varying from a few to about $100 \mathrm{~d}$. Assuming steady state and negligible advection, the ${ }^{234} \mathrm{Th}$-normalised particulate organic carbon (POC) export flux is defined as the product of the flux of ${ }^{234} \mathrm{Th}$ and the POC: ${ }^{234} \mathrm{Th}$ ratio of sinking particles.

Particulate and dissolved ${ }^{234} \mathrm{Th}$ were pre-concentrated by filtration of large volumes of water (700 to 1000 l) using battery-powered in situ pumps. Seawater was pumped at a flow rate of 8 to $101 \mathrm{~min}^{-1}$ through a prefilter $(10 \mu \mathrm{m}$, Nitex $)$ to collect suspended particles, then a polypropylene cartridge $(0.5 \mu \mathrm{m})$ to retain the particulate matter and $2 \mathrm{MnO}_{2}$ impregnated cartridges (1 $\mu \mathrm{m}$, polypropylene), in series, to extract dissolved thorium.

The particles collected with prefilters were then sonicated, divided in 3 aliquots and collected with 3 pre-combusted GF/F filters of $25 \mathrm{~mm}$ diameter. One filter was used for ${ }^{234} \mathrm{Th}$ evaluation on sinking particles by direct beta-counting. The other 2 filters were used for POC measurements, with a CHN Elemental Analyzer (Hedges \& Stern 1984), thus allowing calculation of the POC: ${ }^{234} \mathrm{Th}$ ratio.

The cartridges were ashed in the laboratory at $450^{\circ} \mathrm{C}$ and the ash obtained was sealed in plastic containers for gamma counting. ${ }^{234} \mathrm{Th}$ activity was calculated from the $63.3 \mathrm{keV}$ emission peak, using an HPGe detector with a carbon fibre window. The calibration was performed by a certified ${ }^{234} \mathrm{Th}:{ }^{238} \mathrm{U}$ source with the same geometry and density. The accuracy of the results was checked by analysing standard reference materials. Thorium activities were corrected for extraction efficiency $(E)$ using:

$$
E=1-\mathrm{MnB} / \mathrm{MnA}
$$

where $\mathrm{MnA}$ and $\mathrm{MnB}$ are the activities measured in the first and second $\mathrm{MnO}_{2}$ cartridge, respectively. The results were decay-corrected and divided by the volume filtered. All samples were counted within 1 mo from the date of sampling. The mean efficiency of the $\mathrm{MnO}_{2}$ cartridges was $88 \pm 5 \% .{ }^{238} \mathrm{U}$ concentration was estimated by its relationship to salinity (Pates \& Muir 2007). A box model was used to estimate the rate of thorium scavenging and removal by sinking particles (Savoye et al. 2006). The data obtained were used to calculate the organic carbon sinking flux, integrated over the whole water column investigated $(2000 \mathrm{~m})$. The organic carbon flux measured at $100 \mathrm{~m}$ depth was extrapolated to the depth $(z)$ at the beginning and end of each zooplankton sampling interval by applying the following equation (Martin et al. 1987):

$$
J_{z}=J_{T} /(z / T) 0.858
$$

where $J_{z}$ is the flux at depth $z$ and $J_{T}$ is the flux measured at depth $T$. The differences between the upper and the lower values gives a measure of the losses of organic carbon from the sinking POC-flux in each depth interval.

\section{Mesozooplankton abundance and biomass}

From each $1 \mathrm{l}$ sample, subsamples (from 1/10 to $1 / 25$ of the original sample, in relation to total abundance), obtained using a Stempel pipette, were observed under a stereomicroscope (Leica Wild M10). The whole 11 sample was checked for the identification of rare species and for micronekton. All organisms were counted and classified at higher taxonomic levels, whereas diagnosis at the species level was carried out only for the most abundant taxa (e.g. copepods, euphausiids, cladocerans, chaetognaths). Data were normalised to the total volume filtered and expressed as ind. $\mathrm{m}^{-3}$.

To better interpret the ETS data, attention was paid to the abundance of crustaceans and gelatinous taxa, to their relative importance, as well as to the distribution in the water column of vertically migrating species, with a focus on life stages of euphausiids (but not on the calyptopis stage; Marschoff et al. 1989, Stuart \& Pillar 1990).

For the biomass estimates, a sub-aliquot of $250 \mathrm{ml}$ from each sample was obtained using a Folsom splitter and was filtered onto a $200 \mu \mathrm{m}$ net, and the retained animals were wet-weighed on an analytical balance according to Tranter (1962). Mesozooplankton biomass was expressed as $\mathrm{mg}$ wet $\mathrm{wt} \mathrm{m}^{-3}$ of filtered seawater.

\section{ETS activity}

In the laboratory, the potential respiration and carbon demand of mesozooplankton was estimated from ETS activities measurements according to Packard (1971), Kenner \& Ahmed (1975), Owens \& King (1975), Koppelmann et al. $(2000,2004)$ and Koppelmann \& Weikert 2003 and calculated using the following equation:

$$
\begin{aligned}
& \operatorname{ETS}_{\text {assay }}(\left(\mu \mathrm{l} \mathrm{O} \mathrm{O}_{2} \mathrm{~g} \text { wet } \mathrm{wt}^{-1} \mathrm{~h}^{-1}\right)= \\
& A_{\text {corr }} \times H \times S \times 60 / 1.42 \times W \times f \times t
\end{aligned}
$$


where $A_{\text {corr }}$ is the absorbance of the sample at $490 \mathrm{~nm}$ corrected for blank and reagents, $H$ is the homogenate volume (in $\mathrm{ml}$ ), $S$ is the reaction mixture volume (in $\mathrm{ml}$ ), 60 converts minutes to hours, 1.42 is the conversion factor of INT-formazan into $\mathrm{O}_{2}$ (in $\left.\mu \mathrm{l}\right), w$ is the wet weight of the incubated sample (in $g$ ), $f$ is the volume of the homogenate in the assay (in $\mathrm{ml}$ ) and $t$ is the incubation time (in min). The samples were incubated at $20^{\circ} \mathrm{C}$, but the activities were adjusted for in situ temperature, assuming an activation energy (Ea) of $13.2 \mathrm{kcal} \mathrm{mol}^{-1}$ for bathypelagic mesozooplankton (Packard et al. 1975) and using the Arrhenius equation:
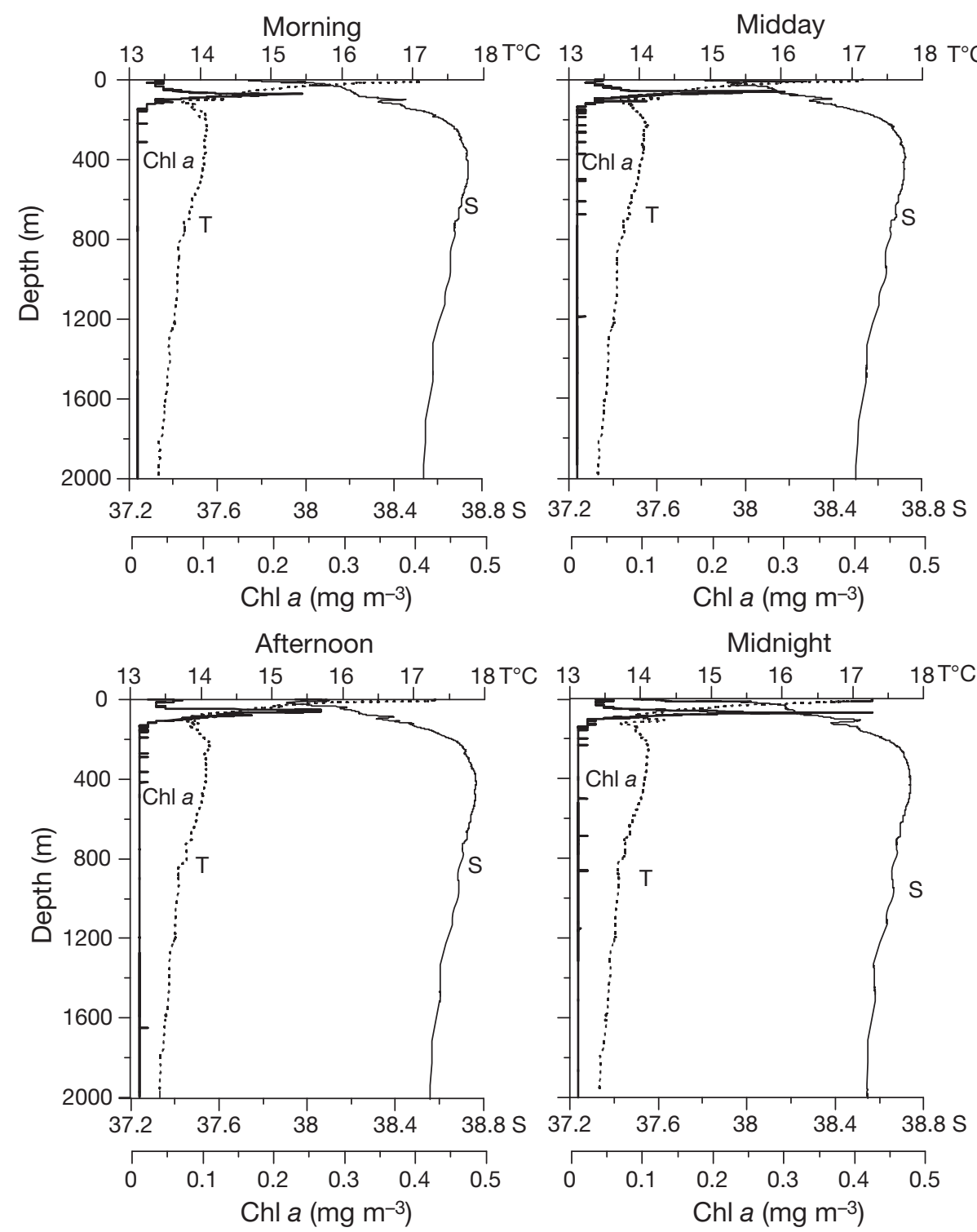

Fig. 2. Vertical profiles of temperature (T), salinity (S) and chl a concentration during the 4 sampling times

$$
\begin{aligned}
& \operatorname{ETS}_{\text {in situ }}\left(\mu \mathrm{l} \mathrm{O}_{2} \mathrm{~g}_{\text {wet }} \mathrm{wt}^{-1} \mathrm{~h}^{-1}\right)= \\
& \operatorname{ETS}_{\text {assay }} \times \mathrm{e}^{\left[\mathrm{Ea} / R \times\left(1 / T_{\text {assay }}-1 / T_{\text {in situ }}\right)\right]}
\end{aligned}
$$

where $R$ is the gas constant, $T_{\text {assay }}$ is the temperature of the assay and $T_{\text {in situ }}$ is the in situ temperature at the time and depth of sampling .

The hourly oxygen consumption rate was converted into daily carbon demand, expressed as $\mu \mathrm{g} \mathrm{C} \mathrm{g} \mathrm{wet}$ $\mathrm{wt}^{-1} \mathrm{~d}^{-1}$, assuming a respiratory quotient of 0.85 (King et al. 1978) and using the following equation:

$$
\begin{aligned}
& \operatorname{ETS}_{\text {assay }}\left(\mu \mathrm{g} \mathrm{Cg} \text { wet } \mathrm{wt}^{-1} \mathrm{~d}^{-1}\right)= \\
& \operatorname{ETS}_{\text {assay }}\left(\mu \mathrm{l} \mathrm{O} \mathrm{O}_{2} \text { g wet } \mathrm{wt}^{-1} \mathrm{~h}^{-1}\right) \times 0.85 \times 12 \times 24 / 22.4
\end{aligned}
$$

where 12 is the weight (in $\mathrm{g}$ ) of 1 mol C, 24 converts hours to days and 22.4 is the gas volume $\mathrm{mol}^{-1}(1)$.

To interface the oxygen consumed measured throughout the ETS methodology to in situ respiration, the ETS:respiration ratio for natural mesozooplankton assemblages is typically assumed to be 0.5 (Kenner \& Ahmed 1975, King \& Packard 1975). Packard (1971) suggested that ETS activity, as measured by INT reduction in homogenates, can be used as a reliable index of in situ oxygen consumption. The values computed for respiration:ETS are correct assuming that the ETS activity is measured at or near the $V_{\max }$ of electron transfer.

\section{RESULTS}

\section{Environmental conditions}

Profiles of water properties $(T, S$, chl a) collected during BIONESS hauls were used to obtain an overall hydrographical picture of the sampling station during the $24 \mathrm{~h}$ cycle. During all 4 sampling times, $\mathrm{T}$ and $\mathrm{S}$ showed similar vertical distribution patterns (Fig. 2). A typical stratified spring situation, with warmer waters at the surface $\left(17.3^{\circ} \mathrm{C}\right.$ in the layer 0 to $\left.20 \mathrm{~m}\right)$ and a thermocline at about $150 \mathrm{~m}$ depth, were observed. Below the 
thermocline and down to the maximum sampling depth, the temperature was about $14^{\circ} \mathrm{C}$. The salinity showed values around 38, with less salt water occupying the upper $300 \mathrm{~m}$ of the water column. Chl a concentrations showed the same vertical distribution pattern at all sampling times: the maximum value was consistently observed at about $80 \mathrm{~m}$ depth and concentrations became almost undetectable below $150 \mathrm{~m}$ depth. Concentration of chl a was higher during the night (0.43 $\mathrm{mg} \mathrm{m}^{-3}$ at midnight).

\section{Mesozooplankton abundance, bio- mass and community composition}

The total number of identified taxa ( $\mathrm{n}=26$ ) remained constant at each sampling time. The total zooplankton weighted abundance, calculated summing up all counted specimens and dividing them by the total volume of filtered seawater, was 18.07, 16.47, 8.09 and 18.31 ind. $\mathrm{m}^{-3}$ in the morning, midday, afternoon and midnight, respectively (Table 1). Over the entire sampling period, copepods were the dominant taxon (representing 79 to $91 \%$ of the total abundance, at midday and in the morning, respectively). Copepod abundance varied from 7.15 ind. $\mathrm{m}^{-3}$ (afternoon) to 16.41 ind. $\mathrm{m}^{-3}$ (morning). The total number of copepod species identified was $67,71,70$ and 75 in the morning, midday, afternoon and midnight samples, respectively.

Overall, both crustaceans and gelatinous mesozooplankton taxa represented relatively invariant fractions (92 to $95 \%$ and 1.7 to $3.2 \%$, respectively) of the total mesozooplankton abundance. For the entire water column, the abundance ratio between gelatinous and crustacean taxa ranged from 1:29 to 1:53. Similar ratios were observed also in the upper $300 \mathrm{~m}$ of the water column (Table S1 in the supplement at www.int-res.com/articles/suppl/m446p091_supp.pdf), a layer in which the daily differences in carbon demand was evidenced.

Looking at the most important group in DVM, the highest abundance of euphausiids (adult + juvenile + furcilia stages) was observed at midnight in the upper $300 \mathrm{~m}$ of the water column, which was also true when considering adults plus juveniles and fur- cilia stages separately (213.4 and 465 ind. $1000 \mathrm{~m}^{-3}$ respectively) (Fig. 3). The abundance and frequency of total euphausiids in the 15 water column layers are reported in Table S2 in the supplement. Overall, 10 euphausiid species were found. Euphausia krohni was always the most abundant euphausiid species, representing from 38 to $55 \%$ of the total euphausiid abundance, with the exception of the afternoon sample, where Nematoscelis megalops became the most

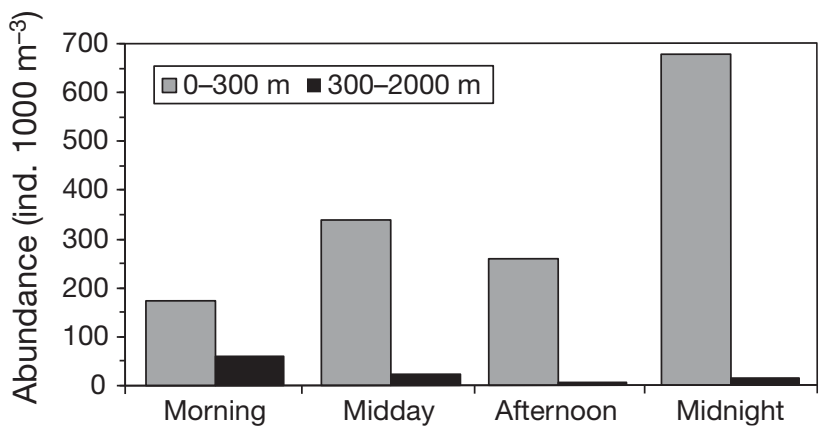

Fig. 3. Mean weighted abundance of euphausiid (adult + juvenile + furcilia stages) in the $0-300 \mathrm{~m}$ and $300-2000 \mathrm{~m}$ layers of the water column during the 4 sampling times 
abundant species $(44 \%$ of the total euphausiid abundance). E. brevis, E. krohni, E. hemigibba, N. megalops and Thysanopoda aequalis showed a clear daily migratory behaviour, whereas $N$. atlantica, Stylocheiron abbreviatum, S. longicorne and Thysanoessa gregaria did not vary their vertical distribution over the entire study period.

The abundance and species composition of migrant copepods did not vary among sampling times. Among these, specific attention was paid to the distribution of strong migrating species, like Paraeuchaeta acuta, Pleuromamma gracilis and Pleuromamma abdominalis, in terms of weighted abundance in the water column layers 0-300 m and 300-2000 m during the 4 sampling times (Table 2). Pleuromamma gracilis was always the most abundant species, representing from 80 to $96 \%$ of total abundance. With the exception of the morning sample, it was followed in decreasing order by Pleuromamma abdominalis and Paraeuchaeta acuta. In the upper $300 \mathrm{~m}$ of the water column, characterised by diel variations in the ETS activity values, the abundance of Paraeuchaeta acuta and Pleuromamma abdominalis did not show variations among the 4 sampling times (Fig. 4). In contrast, the abundance of Pleuromamma gracilis in the morning (3.68 ind. $\left.\mathrm{m}^{-3}\right)$ and at midnight $\left(2.56\right.$ ind. $\left.\mathrm{m}^{-3}\right)$ was much higher than at midday (0.49 ind. $\mathrm{m}^{-3}$ ) and in the afternoon (0.93 ind. $\mathrm{m}^{-3}$ ).

Generally, during the entire sampling period, mesozooplankton biomass decreased with increasing water depth. The highest values of mesozooplankton

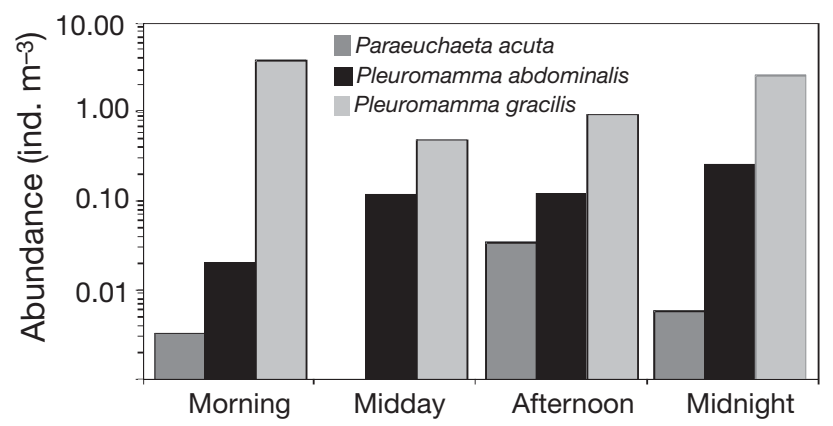

Fig. 4. Mean weighted abundance of strong migrant copepod species in the upper $300 \mathrm{~m}$ of the water column during the 4 sampling times ( $y$-axis in log scale) wet-weighed biomass were found in the $60-80 \mathrm{~m}$ layer of the water column at all sampling times, with the exception of the afternoon sample, in which the highest biomass was observed in the $20-40 \mathrm{~m}$ layer (Fig. 5). In the upper $300 \mathrm{~m}$ of the water column, a progressive increase in zooplankton biomass was observed, from $80 \mathrm{mg}$ wet wt $\mathrm{m}^{-3}$ in the morning and midday samplings, to 140 and $170 \mathrm{mg}$ wet wt $\mathrm{m}^{-3}$ in the afternoon and midnight samplings, respectively.

\section{Zooplankton carbon requirement}

Mesozooplankton carbon demand during the 4 hauls (morning, midday, afternoon and midnight) showed a different vertical distribution pattern from diurnal to nocturnal hours (Table 3).

Mesozooplankton carbon requirement below $300 \mathrm{~m}$ depth remained almost constant during all sampling times, with the exception of the midday sampling, when values were slightly higher than at all other sampling times (Fig. 6). Mean values of mesozooplankton carbon requirement in the upper $300 \mathrm{~m}$ of the water column were 279, 142, 153 and $270 \mu \mathrm{g} \mathrm{C} \mathrm{g}^{-1} \mathrm{~d}^{-1}$ in the morning, midday, afternoon and midnight samples, respectively. Below $300 \mathrm{~m}$ depth, mesozooplankton carbon requirement was 160, 200, 166 and $165 \mu \mathrm{g} \mathrm{C} \mathrm{g}^{-1} \mathrm{~d}^{-1}$, respectively.

Carbon requirement in the 0-2000 m water column layer, normalised per mesozooplankton wet biomass 


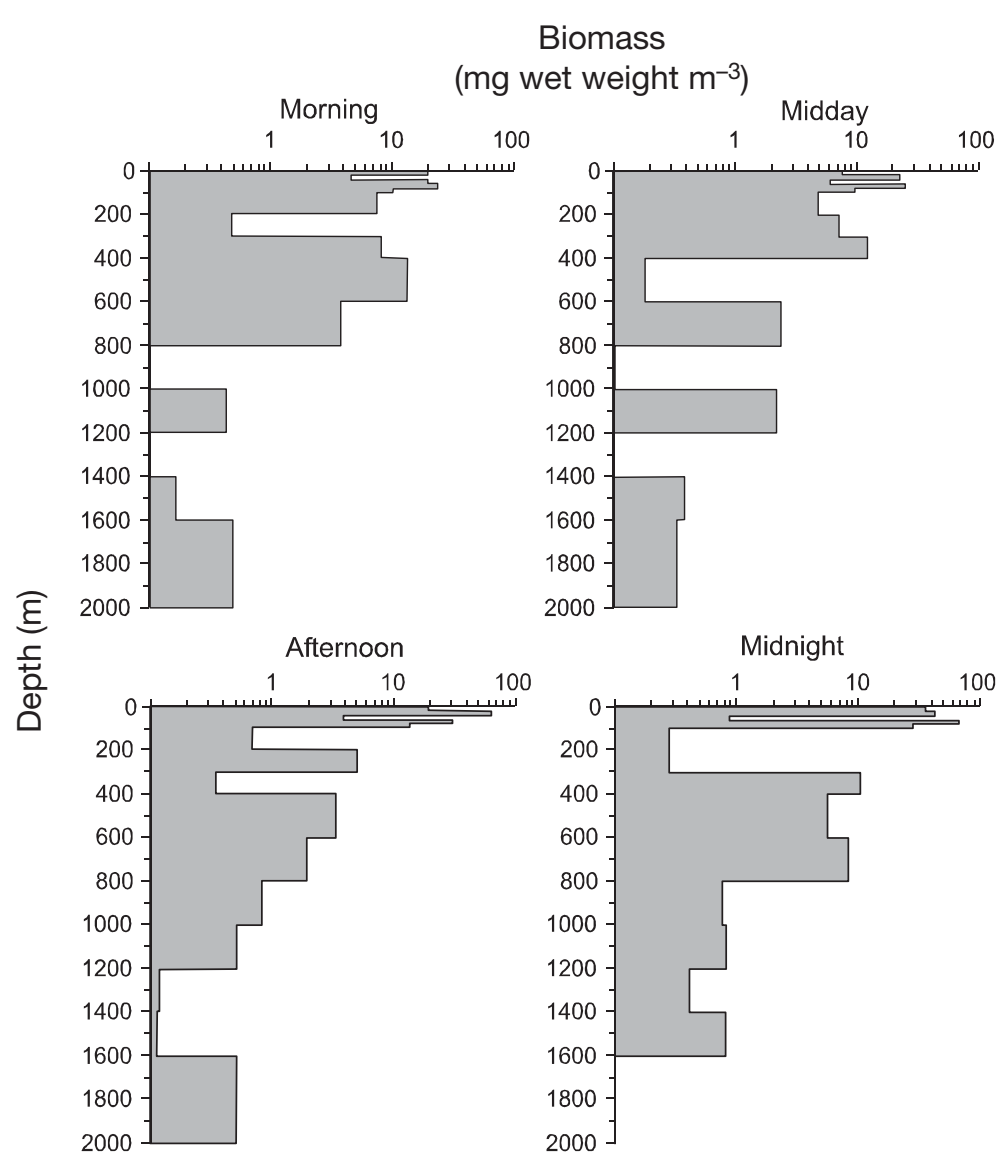

Fig. 5. Vertical distribution of mesozooplankton wet weight biomass down the sampled water column during the $24 \mathrm{~h}$ cycle ( $x$-axis in log scale)

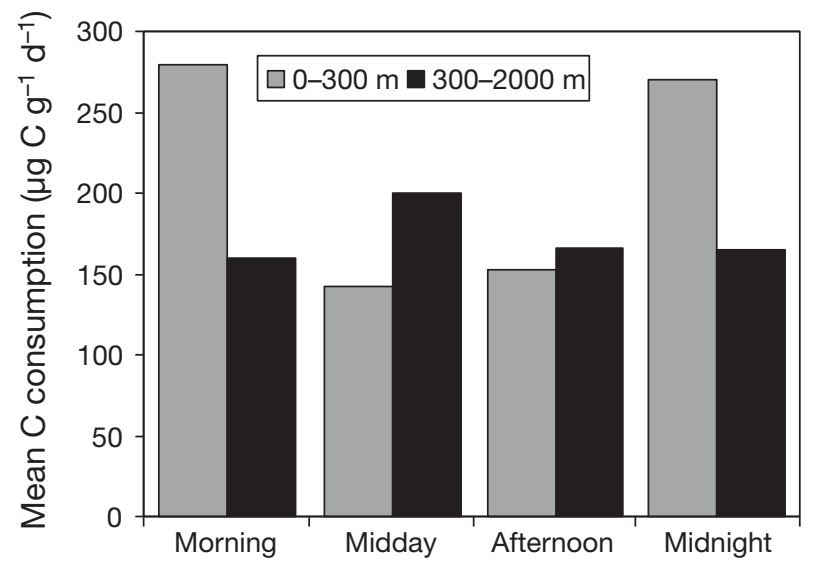

Fig. 6. Carbon requirement mean values, calculated by electron transport system activity, per gram of mixed zooplankton in the $0-300 \mathrm{~m}$ and 300-2000 m layers of the water column during the 4 sampling times
Table 3. Carbon demand of mesozooplankton (determined by electron transport system activity) during the 4 sampling periods from 0 to $2000 \mathrm{~m}$ depth. nd: not detected

\begin{tabular}{|c|c|c|c|}
\hline Sampling & $\begin{array}{l}\text { Layer } \\
(\mathrm{m})\end{array}$ & $\begin{array}{l}\text { In situ } \\
\text { tempe- } \\
\text { rature }\left({ }^{\circ} \mathrm{C}\right)\end{array}$ & $\begin{array}{c}\text { Carbon } \\
\text { demand } \\
\left(\mu g \mathrm{Cg}^{-1} \mathrm{~d}^{-1}\right)\end{array}$ \\
\hline \multirow{15}{*}{$\begin{array}{c}\text { Morning } \\
06: 00\end{array}$} & $0-20$ & 15.78 & 397 \\
\hline & $20-40$ & 14.89 & 317 \\
\hline & $40-60$ & 14.43 & 320 \\
\hline & $60-80$ & 13.97 & 242 \\
\hline & $80-100$ & 13.88 & 261 \\
\hline & $100-200$ & 14.03 & 280 \\
\hline & $200-300$ & 14.08 & 133 \\
\hline & $300-400$ & 14.06 & 141 \\
\hline & $400-600$ & 13.94 & 179 \\
\hline & $600-800$ & 13.79 & 159 \\
\hline & $800-1000$ & 13.59 & nd \\
\hline & $1000-1200$ & 13.62 & 169 \\
\hline & $1200-1400$ & 13.48 & 155 \\
\hline & $1400-1600$ & 13.37 & 165 \\
\hline & $1600-2000$ & 13.42 & 151 \\
\hline \multirow{15}{*}{$\begin{array}{r}\text { Midday } \\
12: 00\end{array}$} & 0-20 & 15.46 & 108 \\
\hline & $20-40$ & 14.78 & 131 \\
\hline & $40-60$ & 14.60 & 177 \\
\hline & $60-80$ & 14.13 & 172 \\
\hline & $80-100$ & 13.84 & 155 \\
\hline & $100-200$ & 14.06 & 108 \\
\hline & $200-300$ & 14.09 & 142 \\
\hline & $300-400$ & 14.06 & 110 \\
\hline & $400-600$ & 13.91 & 203 \\
\hline & $600-800$ & 13.80 & 153 \\
\hline & $800-1000$ & 13.59 & 222 \\
\hline & $1000-1200$ & 13.61 & 204 \\
\hline & $1200-1400$ & 13.48 & 232 \\
\hline & $1400-1600$ & 13.50 & 239 \\
\hline & $1600-2000$ & 13.42 & 233 \\
\hline \multirow{15}{*}{$\begin{array}{c}\text { Afternoon } \\
18: 00\end{array}$} & 0-20 & 16.04 & 119 \\
\hline & $20-40$ & 15.09 & 116 \\
\hline & $40-60$ & 14.34 & 199 \\
\hline & $60-80$ & 14.13 & 96 \\
\hline & $80-100$ & 14.32 & 127 \\
\hline & $100-200$ & 14.08 & 137 \\
\hline & $200-300$ & 14.08 & 275 \\
\hline & $300-400$ & 14.07 & 149 \\
\hline & $400-600$ & 13.92 & 113 \\
\hline & $600-800$ & 13.80 & 109 \\
\hline & $800-1000$ & 13.59 & 246 \\
\hline & $1000-1200$ & 13.64 & 198 \\
\hline & $1200-1400$ & 13.46 & 133 \\
\hline & $1400-1600$ & 13.45 & 244 \\
\hline & $1600-2000$ & 13.42 & 137 \\
\hline \multirow{15}{*}{$\begin{array}{c}\text { Midnight } \\
24: 00\end{array}$} & 0-20 & 15.82 & 325 \\
\hline & $20-40$ & 14.93 & 328 \\
\hline & $40-60$ & 14.29 & 305 \\
\hline & $60-80$ & 13.93 & 218 \\
\hline & $80-100$ & 13.86 & 226 \\
\hline & $100-200$ & 14.07 & 276 \\
\hline & $200-300$ & 14.07 & 210 \\
\hline & $300-400$ & 14.03 & 100 \\
\hline & $400-600$ & 13.93 & 120 \\
\hline & $600-800$ & 13.80 & 233 \\
\hline & $800-1000$ & 13.67 & 137 \\
\hline & $1000-1200$ & 13.62 & 227 \\
\hline & $1200-1400$ & 13.47 & 197 \\
\hline & $1400-1600$ & 13.37 & 128 \\
\hline & $1600-2000$ & 13.42 & 181 \\
\hline
\end{tabular}




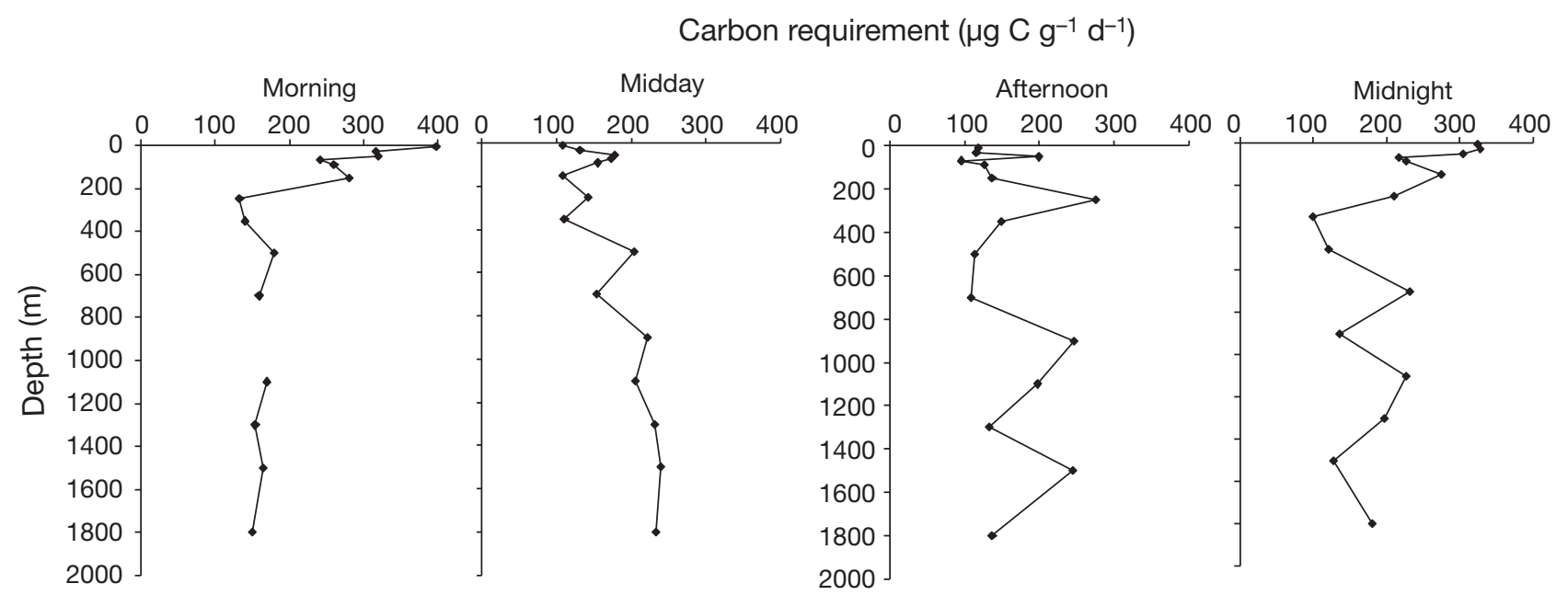

Fig. 7. Vertical diel in situ carbon requirement distribution from the surface to $2000 \mathrm{~m}$ depth during the 4 sampling times

unit, was characterised by higher values in the morning and midnight, than in midday and afternoon samples (Fig. 7).

The mesozooplankton carbon requirement, expressed as $\mu \mathrm{g} \mathrm{C} \mathrm{m} \mathrm{m}^{-3} \mathrm{~d}^{-1}$, of the entire mesozooplanktonic community for each water column layer, calculated by multiplying the biomass value ( $\mathrm{g}$ wet $\mathrm{wt}$ $\mathrm{m}^{-3}$ ) by the estimated carbon demand ( $\mu \mathrm{g}$ $\mathrm{C} \mathrm{g}^{-1} \mathrm{~d}^{-1}$ ), were analysed. During entire $24 \mathrm{~h}$ sampling cycle, the mesozooplankton carbon requirement showed the same vertical distribution, with the highest values consistently observed above $80 \mathrm{~m}$ depth during the entire sampling period (Fig. 8).

\section{Mesozooplankton contribution to carbon losses from the sinking flux}

Even though it was possible to measure the organic carbon downward flux from $20 \mathrm{~m}$ depth down to the maximum sampled depth, we show the results starting from $100 \mathrm{~m}$ depth, because the organisms in the epipelagic zone depend mainly on primary production as supported by the chl a maximum measured at $80 \mathrm{~m}$ depth, where mixing processes cannot be overlooked. During the study period, organic carbon downward flux at $100 \mathrm{~m}$ (58 mg C $\mathrm{m}^{-2} \mathrm{~d}^{-1}$ ) was about 13-fold higher than that measured at $2000 \mathrm{~m}$ depth $(4.44 \mathrm{mg}$ $\mathrm{C} \mathrm{m}^{-2} \mathrm{~d}^{-1}$ ) (Table 4). Thus, the estimated

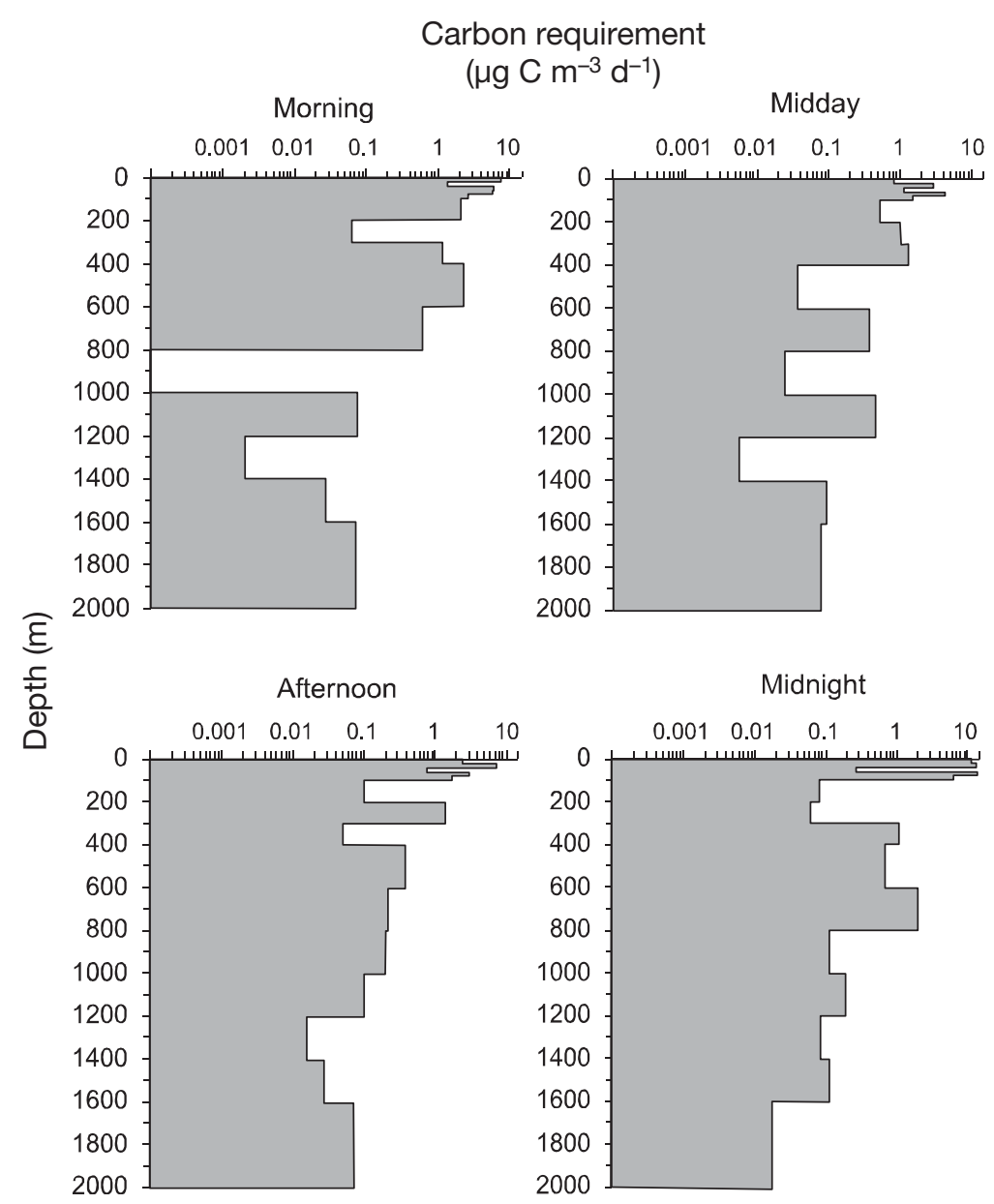

Fig. 8. Vertical distribution of mesozooplankton metabolic carbon requirements down the sampled water column during the $24 \mathrm{~h}$ cycle ( $x$-axis in log scale) 
Table 4. Sinking organic carbon flux calculated from the ${ }^{234} \mathrm{Th}:{ }^{238} \mathrm{U}$ disequilibrium at a fixed station in the Tyrrhenian Sea in April 2007. Calculations based on the estimated flux of $58.00 \mathrm{mg} \mathrm{C} \mathrm{m}^{-2} \mathrm{~d}^{-1}$ at $100 \mathrm{~m}$. The flux rate is extrapolated to the depth of the beginning/end of each sampled layer and the carbon losses from the sinking flux are calculated. The carbon used by mesozooplankton and its contribution to the carbon losses are shown as means over the 4 sampling times

\begin{tabular}{|c|c|c|c|c|c|}
\hline $\begin{array}{l}\text { Sampling } \\
\text { layer } \\
\text { (m) }\end{array}$ & $\begin{array}{c}\text { Sinking } \\
\text { flux } \\
\left(\mathrm{mg} \mathrm{C} \mathrm{m}^{-2} \mathrm{~d}^{-1}\right)\end{array}$ & $\begin{array}{c}\text { Carbon } \\
\text { losses } \\
\left(\mathrm{mg} \mathrm{C} \mathrm{m}^{-2} \mathrm{~d}^{-1}\right)\end{array}$ & $\begin{array}{c}\text { Carbon } \\
\text { respired } \\
\left(\mu \mathrm{g} \mathrm{m}^{-2} \mathrm{~d}^{-1}\right)\end{array}$ & $\begin{array}{c}\text { Zooplankton } \\
\text { biomass } \\
\text { (mg wet wt } \mathrm{m}^{-2} \text { ) }\end{array}$ & $\begin{array}{c}\text { Zooplankton } \\
\text { contribution } \\
(\%)\end{array}$ \\
\hline $100-200$ & 58.00 & 26.00 & 69 & 329 & 0.27 \\
\hline $200-300$ & 32.00 & 9.40 & 64 & 327 & 0.68 \\
\hline $300-400$ & 22.60 & 4.94 & 90 & 775 & 1.81 \\
\hline $400-600$ & 17.65 & 5.19 & 173 & 1122 & 3.33 \\
\hline $600-800$ & 12.47 & 2.73 & 158 & 834 & 5.81 \\
\hline $800-1000$ & 9.74 & 1.70 & 23 & 89 & 1.34 \\
\hline $1000-1200$ & 8.04 & 1.16 & 41 & 203 & 3.55 \\
\hline $1200-1400$ & 6.88 & 0.85 & 5 & 29 & 0.63 \\
\hline $1400-1600$ & 6.03 & 0.65 & 13 & 77 & 2.00 \\
\hline $1600-2000$ & 5.37 & 0.94 & 24 & 145 & 2.60 \\
\hline Max. sampled depth & 4.44 & & & & \\
\hline
\end{tabular}

carbon loss during particle descent down to $2000 \mathrm{~m}$ depth was about $92 \%\left(53.56 \mathrm{mg} \mathrm{C} \mathrm{m}^{-2} \mathrm{~d}^{-1}\right)$ of the flux at the surface, of which the largest fraction was lost within the top $1000 \mathrm{~m}$. From 1000 to $2000 \mathrm{~m}$ depth, the carbon loss was only $3.61 \mathrm{mg} \mathrm{C} \mathrm{m}^{-2} \mathrm{~d}^{-1}$.

\section{DISCUSSION}

The present study provides new information about the vertical distribution of the mesozooplankton carbon requirement down to $2000 \mathrm{~m}$ water depth in the open Tyrrhenian Sea, with clues about its role in the pelagic carbon flow within this pelagic ecosystem. The estimate of zooplankton respiration through ETS activity measurement represents an easy and advantageous method (Packard 1971, King \& Packard 1975) which is well correlated with in vivo respiration rates (Packard et al. 1974, Kenner \& Ahmed 1975, Owens \& King 1975, Devol \& Packard 1978). Since concomitant in situ measurements of respiration and ETS are not available for the deep sea, we could not give error values for the respiration:ETS ratio used. This relationship, as shown by Arístegui \& Montero (1995), was not different with respect to other methods that measure other planktonic metabolic processes (Richardson 1991). The ETS method can therefore be useful for obtaining data on carbon requirements in bathypelagic environments below $1000 \mathrm{~m}$ water depth, an oceanic region very poorly investigated to date in this respect (Koppelmann \& Weikert 1999, Koppelmann et al. 2000). Table 5 lists some in situ (Smith 1982, 1985, Smith et al. 1986) and ETS-estimated (Koppelmann et al. 2000, 2004, Hals-
band-Lenk et al. 2003) respiration measurements, for the Pacific Ocean and for the Levantine and Arabian Seas, respectively.

The vertical distribution of mesozooplankton carbon requirement per unit biomass in the upper $300 \mathrm{~m}$ of the water column varied considerably among sampling periods, whereas it remained almost constant at deeper depths. Above $300 \mathrm{~m}$ depth, ETS activities in the morning and midnight samples were higher than in the midday and afternoon samples. Since the ETS activity was standardised per unit of biomass, variations in the zooplankton abundance cannot explain the observed temporal variations, though the oxygen demand is a function of body mass (Ikeda et al. 2001). Moreover, the minor changes in the community composition of mesozooplankton and in the values of the abundance ratio of gelatinous taxa over crustaceans during the different sampling times are most likely not responsible for the observed temporal variations in ETS activity. The abundance of copepod, euphausiid and decapod carcasses (about 0.01 carcasses $\mathrm{m}^{-3}$ for each replicate) was very low and did not show variations during the study period, suggesting that the ratio between carcasses and living specimens did not have a relevant role in controlling variations in carbon requirement estimates among sampling periods.

We paid particular attention to actively migrating organisms that mediate the vertical transport of material towards the ocean's interior (Longhurst 1976, Longhurst et al. 1990). Vertically migrant zooplankton and micronekton feed in surface waters and excrete at depth, potentially supporting microbial growth in the mesopelagic zone by actively transporting dis- 
Table 5. Zooplankton carbon consumption data from the literature. All data were recalculated for the in situ temperature $\left(\sim 14^{\circ} \mathrm{C}\right)$ of the Tyrrhenian Sea, using the Arrhenius equation. ETS: electron transport system

\begin{tabular}{|c|c|c|c|c|c|}
\hline Area & $\begin{array}{l}\text { Depth } \\
\text { (m) }\end{array}$ & $\begin{array}{l}\text { Mesh } \\
\text { size } \\
(\mu \mathrm{m})\end{array}$ & $\begin{array}{c}\text { Carbon } \\
\text { consumption } \\
(\mu g \mathrm{Cg} \text { wet } \\
\left.\mathrm{wt}^{-1} \mathrm{~d}^{-1}\right)\end{array}$ & Source & Notes \\
\hline \multirow[t]{3}{*}{ Levantine Sea } & $\begin{array}{l}425 \text { day/night } \\
1350 \\
2750 \\
4250\end{array}$ & 333 & $\begin{array}{c}665 / 361 \\
377 \\
860 \\
275\end{array}$ & Koppelmann et al. (2004) & ETS \\
\hline & $\begin{array}{l}425 \text { day/night } \\
1350 \\
2750 \\
4250\end{array}$ & 100 & $\begin{array}{c}1242 / 578 \\
573 \\
310 \\
139\end{array}$ & Halsband-Lenk et al. (2003) & ETS \\
\hline & $\begin{array}{l}425 \text { day/night } \\
1350 \\
2750 \\
4250\end{array}$ & 333 & $\begin{array}{c}665 / 361 \\
377 \\
860 \\
275\end{array}$ & Halsband-Lenk et al. (2003) & \\
\hline Arabian Sea & $\begin{array}{l}1050 \\
2500 \\
4000\end{array}$ & 333 & $\begin{array}{l}676 \\
711 \\
445\end{array}$ & Koppelmann et al. (2000) & ETS \\
\hline Pacific Ocean & $\begin{array}{l}1300 \\
2615 \\
3850\end{array}$ & 297 & $\begin{array}{l}377 \\
712 \\
433\end{array}$ & $\begin{array}{l}\text { Smith (1982) } \\
\text { Smith (1985) } \\
\text { Smith et al. (1986) }\end{array}$ & $\begin{array}{l}\text { In situ measurement } \\
\text { In situ measurement } \\
\text { In situ measurement }\end{array}$ \\
\hline
\end{tabular}

solved and particulate organic material (Longhurst et al. 1990, Burd et al. 2010). The total euphausiid abundance showed a typical vertical migration in the present study, with the highest densities typically observed above $100 \mathrm{~m}$ water depth during the dark hours. The 3 Euphausia species, Nematoscelis megalops and Thysanopoda aequalis all showed strong migratory behaviours, whereas $N$. atlantica, the 2 species of Stylocheiron and Thysanoessa gregaria consistently occupied the same water column layers during the entire $24 \mathrm{~h}$ sampling period. Meganyctiphanes norvegica was almost totally absent in our samples because it easily avoids the sampling device employed in the present study (Sameoto et al. 1993, Wiebe et al. 2004). The vertical distribution pattern of euphausiids does not seem to be at all correlated to the carbon consumption vertical trend during the 24 h cycle. As previously reported (Torres et al. 1979, Schalk 1988, Minutoli \& Guglielmo 2009), at midday, afternoon and midnight, the vertical distribution of ETS activity in the present study resembled that of euphausiid abundance. On the other hand, in the morning, the high values of ETS activity were not associated with high euphausiid abundance. The high carbon demand observed above $300 \mathrm{~m}$ water depth in the morning samples is likely attributable to an actively migrant species, the calanoid copepod Pleuro- mamma gracilis, which was extremely abundant (3679 ind. $1000 \mathrm{~m}^{-3}$ ), representing about $6 \%$ of the total mesozooplankton abundance in the same water column layer and sampling time. These results are in agreement with several previous studies which reported that in the pelagic environment, diel-migrant zooplankton have a higher respiratory activity than deeper-living and/or non-migrating zooplankton species (Childress 1969, 1971, 1975, Jannasch \& Wirsen 1973, Packard et al. 1975, Jannasch et al. 1976, Torres et al. 1979).

The vertical distribution of zooplankton wet biomass increased from the morning to the dark hours, as previously reported, and not merely due to the increasing haul effectiveness at night (HernándezLeón et al. 2001, Yebra et al. 2005). At night, the migrant organisms ascend for feeding, while during daylight hours, they return to deeper waters to avoid visual predators. This behaviour means that at night time, the majority of the zooplankton biomass is concentrated in the uppermost $300 \mathrm{~m}$ of the water column (Brinton 1967, Vinogradov 1968, Mauchline \& Fisher 1969, Casanova 1974, Brancato et al. 2001, Yebra et al. 2005).

The mesh size of the net employed during the present study could have led to underestimating the abundance of some small copepod species $(<0.5 \mathrm{~mm})$ 
and their early stages. Nevertheless, the BIONESS efficiently collects euphausiids and the migrant copepod species analysed in the present study (Herman 1992, 2001, Calbet et al. 2001).

The downward flux of POC is generally regarded as the most important source of organic carbon for the meso- and bathypelagic zones (Burd et al. 2010). Sediment traps are the most common tools for estimating sinking fluxes, though their use has many documented accuracy issues (Lee et al. 1988), especially in the upper $1000 \mathrm{~m}$ of the water column (Buesseler et al. 2007, Burd et al. 2010). The disequilibrium ${ }^{234} \mathrm{Th}:{ }^{238} \mathrm{U}$ method can be considered as a valid alternative for most of the depth intervals under scrutiny in the present study. Furthermore, the use of this method avoids the underestimation of the carbon availability at great depths, and it has been even used to correct flux data estimated using sediment traps (Scholten et al. 2001, Halsband-Lenk et al. 2003). Changes in POC flux with depth are often estimated using regression equations, including the Martin curve (Martin et al. 1987), from the literature, rather than by direct observation, relating flux at depth to a known flux at a given depth. The regression equations that relate water depth and the POC flux can be used to estimate the POC removed by heterotrophic consumption. In the present study, the carbon flux, estimated from the ${ }^{234} \mathrm{Th}:{ }^{238} \mathrm{U}$ disequilibrium at $100 \mathrm{~m}$ depth and then integrated for the entire water column using the equation suggested by Martin et al. (1987), decreased from 100 to $2000 \mathrm{~m}$ depth (Table 4).

The relative contribution of zooplankton respiration to the decrease in POC flux varies spatially, temporally and also vertically (Burd et al. 2010). The metabolic requirement of the mesozooplankton in the open Tyrrhenian Sea ranged from 0.27 to $5.81 \%$ of the measured carbon losses (Table 4). Higher remineralisation values occurred below $300 \mathrm{~m}$ depth, with a mean value of $2.75 \%$, about 3 times higher than in the upper $300 \mathrm{~m}$ of the water column $(0.92 \%)$. Mesozooplankton carbon requirements can be assumed to be approximately $30 \%$ of the microplankton requirements in bathypelagic environment (King et al. 1978, Packard et al. 1988), so that the majority of carbon losses are likely due to requirements by other zooplankton size classes, including microplankton and heterotrophic prokaryotes, as well as by the transfer of organic carbon into the dissolved pool (King et al. 1978, Packard et al. 1988, Koppelmann et al. 2000). In the present study, the percentage contribution of mesozooplankton respiration to organic carbon losses for the meso- and bathy- pelagic zones were $13.24 \%$ from 100 to $1000 \mathrm{~m}$ depth and $8.78 \%$ from 1000 to $2000 \mathrm{~m}$ depth. These results are in agreement with previous studies (Martin et al. 1987, Burd et al. 2010). In the epipelagic waters, the contribution of mesozooplankton respiration was very low $(1.42 \%)$, indicating the dominance of autrotrophic processes in this upper layer of the water column. The mesopelagic layer, mostly characterised by heterotrophic activities, however accounts for the bulk of the decrease in particulate organic sinking flux (Martin et al. 1987). Below 1000 m water depth, the respiration by mesozooplankton decreases again because of the decrease in abundance values.

In the bathypelagic zone of the Arabian Sea, Koppelmann et al. (2000) estimated a mesozooplankton metabolic requirement of about 4 to $5 \%$ of the measured carbon losses. The feeding strategies and behaviour of meso- and bathypelagic zooplankton differ from their epipelagic counterparts (Wishner et al. 2000, Koppelmann et al. 2009), so that it can be inferred that meso-, bathy- and epipelagic zooplankton communities play different roles in the carbon binding activity in these 3 ecological zones along the water column.

Even if the low chlorophyll concentration, zooplankton abundance and biomass, and POM sinking flux confirmed the oligotrophic status of the open Tyrrhenian Sea, the percentage contribution of mesozooplankton to the carbon losses reflects the less oligotrophic conditions compared to the central and eastern parts of the Mediterranean Sea (Scotto di Carlo \& Ianora 1983, Weikert \& Trinkaus 1990, Kerhervé et al. 1999). Our results show that, in the open southern Tyrrhenian Sea, mesozooplankton may contribute to a certain extent to the carbon losses during particle descent and that their metabolism represents a relatively important pathway for carbon cycling in epipelagic waters (Thiel 1983, Tselepides \& Eleftheriou 1992).

Acknowledgements. This study was undertaken in the framework of the project VECTOR, led by the National Italian Consortium for Marine Science (CoNISMa) and funded by the Italian Ministry of University and Research (MIUR). Our local research unit (CoNISMa Messina) was involved in Line 8 of the project, named 'CARPEL' (The CARbon cycle in the PELagic area of the Mediterranean). The authors are grateful to Dr. R. Koppelmann (Institute for Hydrobiology and Fisheries Science, Hamburg University, Germany) for kind assistance in data checking and for continuous scientific support, to Dr. A. Schirone (Centro Ricerche Ambiente Marino, S. Teresa, Enea, La Spezia, Italy) for the ${ }^{234} \mathrm{Th}:{ }^{238} \mathrm{U}$ disequilibrium data and to Prof. A. Pusceddu (Department of Life and Environmental Science, Polytechnic University of Marche, Ancona, Italy) for English revision and critical reading of an early version of the manuscript. 
Many thanks are due to the crew of the oceanographic vessel 'Universitatis' for the kind availability and help provided in daily and nightly collection of biological samples.

\section{LITERATURE CITED}

Anraku M (1964) Influence of the Cape Cod Canal on the hydrography and on the copepods in Buzzards Bay and Cape Cod Bay, Massachusetts. II: Respiration and feeding. Limnol Oceanogr 9:195-206

Arístegui J, Montero MF (1995) The relationship between community respiration and ETS activity in the ocean. J Plankton Res 17:1563-1571

> Azam F, Fenchel T, Field JC, Gray JS, Meyer-Reil LA, Thingstad F (1983) The ecological role of water-column microbes in the sea. Mar Ecol Prog Ser 10:257-263

Båmstedt U (1979) Seasonal variation in respiratory rate and ETS activity of deep water zooplankton from the Swedish west coast. In: Naylor E, Hartnoll RG (eds) Proc 13th Eur Mar Biol Symp. Pergamon Press, Oxford, p 267-274

Båmstedt U (1980) ETS activity as an estimator of respiratory rate of zooplankton populations. The significance of variations in an environmental factor. J Exp Mar Biol Ecol 42: 267-283

Berger WH, Smetacek VS, Wefer G (1988) Ocean productivity and paleoproductivity. Life Sci Res Rep 44:1-34

Bidigare RR, King FD, Biggs DC (1982) Glutamate dehydrogenase $(\mathrm{GDH})$ and respiratory electron-transport system (ETS) activities in Gulf of Mexico zooplankton. J Plankton Res 4:895-911

Brancato G, Minutoli R, Granata A, Sidoti O, Guglielmo L (2001) Diversity and vertical migration of Euphausiids across the Straits of Messina area. In: Faranda FM, Guglielmo L, Spezie G (eds) Mediterranean ecosystems: structure and processes. Springer Verlag, Milan, p 131-141

Brinton E (1967) Vertical migration and avoidance capability of euphausiids in the California Current. Limnol Oceanogr 12:451-483

Buesseler KO, Bacon MP, Cochran JK, Livingston HD (1992) Carbon and nitrogen export during the JGOFS North Atlantic Bloom Experiment estimated from ${ }^{234} \mathrm{Th}^{238} \mathrm{U}$ disequilibria. Deep-Sea Res A 39:1115-1137

Buesseler KO, Antia AN, Chen M, Fowler SW and others (2007) An assessment of the use of sediment traps for estimating upper ocean particle fluxes. J Mar Sci 65: 345-416

Burd AB, Hansell DA, Steinberg DK, Anderson TR and others (2010) Assessing the apparent imbalance between geochemical and biochemical indicators of meso- and bathypelagic biological activity: What the @\$\#! is wrong with present calculations of carbon budgets? Deep-Sea Res II 57:1557-1571

Calbet A, Garrido S, Saiz E, Alcaraz M, Duarte CM (2001) Annual zooplankton succession in coastal NW Mediterranean waters: the importance of the smaller size fractions. J Plankton Res 23:319-331

Casanova B (1974) Les Euphausiacés de Méditerranée: systématique et développement larvaire: biogéographie et biologie. PhD thesis, Université de Provence, Marseille

Childress JJ (1969) The respiratory physiology of the oxygen minimum layer mysid Gnathophausia ingens. $\mathrm{PhD}$ dissertation, Stanford University

Childress JJ (1971) Respiratory rate and depth of occurrence of midwater animals. Limnol Oceanogr 16:104-106

Childress JJ (1975) The respiratory rates of midwater crustaceans as a function of depth of occurrence and relation to the oxygen minimum layer off Southern California. Comp Biochem Physiol A 50:787-799

Devol AH, Packard TT (1978) Seasonal changes in respiratory enzyme activity and productivity in Lake Washington microplankton. Limnol Oceanogr 23:104-111

Fabiano M, Pusceddu A, Dell'Anno A, Armeni M and others (2001) Fluxes of phytopigments and labile organic matter to the deep ocean in the NE Atlantic Ocean. Prog Oceanogr 50:89-104

Halsband-Lenk C, Koppelmann R, Weikert H (2003) Carbon requirements of deep-sea zooplankton estimated from ETS measurements in relation to size fraction and taxonomic composition. In: Yalmaz A (ed) Oceanography of Eastern Mediterranean and Black Sea. Tubitak, Ankara, p 805-813

Hedges JI, Stern JH (1984) Carbon and nitrogen determination of carbonate-containing solids. Limnol Oceanogr 29: 657-663

> Herman AW (1992) Design and calibration of a new optical plankton counter capable of sizing small zooplankton. Deep-Sea Res A 39:395-425

Herman AW (2001) A review of OPC and an introduction to the next generation of OPC: the laser OPC. In: GLOBEC Report No. 17, Optical Plankton Counter Workshop (1720 June 2001), Tromsø, Norway. GLOBEC, Plymouth, $\mathrm{UK}, \mathrm{p}$ 3-6

> Hernández-León S, Gomez MM, Pagazaurtundua M, Portillo-Hahnefeld A, Montero I, Almeida C (2001) Vertical distribution of zooplankton in Canary Island waters: implication for export flux. Deep-Sea Res I 48: 1071-1092

> Hirche HJ (1984) Temperature and metabolism of plankton. I. Respiration of Antarctic zooplankton at different temperatures with a comparison of Antarctic and Nordic krill. Comp Biochem Physiol A 77:361-368

Ikeda T, Fay EH (1981) Metabolic activity of zooplankton from the Antarctic Ocean. Aust J Mar Freshw Res 32: 921-930

Ikeda T, Kanno Y, Ozaki K, Shinada A (2001) Metabolic rates of epipelagic marine copepods as a function of body mass and temperature. Mar Biol 139:587-596

Jannasch HW, Wirsen CO (1973) Deep-sea microorganisms: in situ response to nutrient enrichment. Science 180: 641-643

> Jannasch HJ, Wirsen CO, Taylor CD (1976) Undecompressed microbial populations from the deep sea. Appl Environ Microbiol 32:360-367

Kenner RA, Ahmed SJ (1975) Measurement of the electron transport activities in marine phytoplankton. Mar Biol 33: 119-127

Kerhervé $\mathrm{P}$, Heussner $\mathrm{S}$, Charrière B, Stavrakakis $\mathrm{S}$, Ferrand JL, Monaco A, Delsaut N (1999) Biogeochemistry and dynamics of settling particle fluxes at the Antikythira Strait (Eastern Mediterannean). Prog Oceanogr 44: 651-675

King FD, Packard TT (1975) Respiration and the activity of the respiratory electron transport system in marine zooplankton. Limnol Oceanogr 20:849-854

King FD, Devol AH, Packard TT (1978) On plankton biomass and metabolic activity from the eastern tropical North Pacific. Deep-Sea Res 25:689-704

Koppelmann R, Frost J (2008) The ecological role of zoo- 
plankton in the twilight and dark zones of the ocean. In: Mertens LP (ed) Biological oceanography research trends. Nova Science Publishers, Hauppauge, NY, p 67-130

Koppelmann R, Weikert H (1999) Temporal changes of deep-sea mesozooplankton abundance in the temperate NE Atlantic and estimates of the carbon budget. Mar Ecol Prog Ser 179:27-40

Koppelmann R, Weikert H (2003) Deep-sea zooplankton ecology of the eastern Mediterranean. State of the art and perspectives. CIESM Workshop Monogr 23:47-53

Koppelmann R, Schafer P, Schiebel R (2000) Organic carbon losses measured by heterotrophic activity of mesozooplankton and $\mathrm{CaCO}_{3}$ flux in bathypelagic zone of the Arabian Sea. Deep-Sea Res II 47:169-187

Koppelmann R, Weikert H, Halsband-Lenk C (2004) Mesozooplankton community respiration and its relation to particle flux in the oligotrophic eastern Mediterranean. Global Biogeochem Cycles 18:GB1039

Koppelmann R, Bottger-Schnack R, Mobius J, Weikert H (2009) Trophic relationships of zooplankton in the eastern Mediterranean based on stable isotope measurements. J Plankton Res 31:669-686

Lee C, Wakeham SG, Hedges JI (1988) The measurement of oceanic particulate flux: Are swimmers a problem? Oceanography (Wash DC) 2:34-36

Longhurst AR (1976) Vertical migration. In: Cushing DH, Walsh JJ (eds) The ecology of the seas. Blackwell Scientific Publications, Oxford, p 116-137

Longhurst AR (1991) Role of the marine biosphere in the global carbon cycle. Limnol Oceanogr 36:1507-1526

> Longhurst AR, Bedo A, Harrison WG, Head EJH, Horne EP, Irwin B, Morales C (1989) NFLUX: a test of vertical nitrogen flux by diel migrant biota. Deep-Sea Res A 36: 1705-1719

Longhurst AR, Bedo AW, Harrison WG, Head EJH, Sameoto DD (1990) Vertical flux of respiratory carbon by oceanic diel migrant biota. Deep-Sea Res A 37:685-694

Marinov I, Sarmiento JL (2004) The role of the oceans in the global carbon cycle: an overview. In: Follows M, Oguz T (eds) Ocean carbon cycle and climate, NATO ASI. Kluwer Academic Publishers, Ankara, p 251-295

> Marschoff ER, Lovrich GA, Calcagno JA (1989) Vertical distribution of two substages of stage Calyptopis I of Euphausia superba Dana, in South Orkneys Area. Polar Biol 9:325-328

Martin JH, Knauer GA, Karl DM, Broenkow WW (1987) VERTEX: carbon cycling in the northeast Pacific. DeepSea Res A 34:267-286

Mauchline J, Fisher LR (eds) (1969) The biology of euphausiids. Academic Press, New York, NY

Middelburg JJ, Meysman FJR (2007) Ocean science: burial at sea. Science 316:1294-1295

Minutoli R, Guglielmo L (2009) Zooplankton respiratory Electron Transport System activity (ETS) in the Mediterranean Sea: spatial and diel variability. Mar Ecol Prog Ser 381:199-211

Musayeva EI, Shushkina EA (1978) Metabolic rates of planktonic animals at different temperatures. Oceanology 18:343-346

> Owens TG, King FD (1975) The measurement of respiratory electron transport system activity in marine zooplankton. Mar Biol 30:27-36

Packard TT (1971) The measurement of electron transport system activity in marine phytoplankton. J Mar Res 29:
235-244

Packard TT, Harmon D, Boucher J (1974) Respiratory electron transport activity in plankton from upwelled waters. Tethys 6:213-222

> Packard TT, Devol AH, King FD (1975) The effect of temperature on the respiratory electron transport system in marine plankton. Deep-Sea Res Oceanogr Abstr 22: 237-249

Packard TT, Denis M, Rodier M, Garfield P (1988) Deepocean metabolic $\mathrm{CO}_{2}$ production: calculation from ETS activity. Deep-Sea Res A 35:371-382

Pates JM, Muir GKP (2007) U-salinity relationships in the Mediterranean: implications for ${ }^{234} \mathrm{Th}:{ }^{238} \mathrm{U}$ particle flux studies. Mar Chem 106:530-545

Raymont JEG (1983) Plankton and productivity in the oceans, Vol 2, Zooplankton. Pergamon Press, Oxford

Richardson K (1991) Comparison of ${ }^{14} \mathrm{C}$ primary production determinations made by different laboratories. Mar Ecol Prog Ser 72:189-201

Sameoto DD, Saroszynsky LO, Fraser WB (1980) BIONESS, a new design in multiple net zooplankton sampler. J Fish Res Board Can 37:722-724

> Sameoto D, Cochrane N, Herman A (1993) Convergence of acoustic, optical, and net-catch estimates of euphausiids abundance: use of artificial light to reduce net avoidance. Can J Fish Aquat Sci 50:334-346

Savoye N, Benitez-Nelson C, Burd AB, Cochran JK and others (2006) ${ }^{234} \mathrm{Th}$ sorption and export models in the water column: a review. Mar Chem 100:234-249

Schalk PH (1988) Respiratory electron transport system (ETS) activities in zooplankton and micronekton of the Indo-Pacific region. Mar Ecol Prog Ser 44:25-35

> Scholten JC, Fietzke J, Vogler S, Rutgers van der Loeff MM and others (2001) Trapping efficiencies of sediment traps from the deep Eastern North Atlantic: the ${ }^{230}$ Th calibration. Deep-Sea Res II 48:2383-2408

Scotto di Carlo B, Ianora A (1983) Standing stocks and species composition of Mediterranean zooplankton. In: Carrada GC et al. (eds) Quantitative analysis and simulation of Mediterranean coastal ecosystem: the Gulf of Naples, a case study. UNESCO Rep Mar Sci 20. UNESCO, Paris, p 59-69

Smith KL Jr (1982) Zooplankton of a bathyal boundary layer: in situ rates of oxygen consumption and ammonium excretion. Limnol Oceanogr 27:461-471

> Smith KL Jr (1985) Macrozooplankton of a deep sea hydrothermal vent: in situ rates of oxygen consumption. Limnol Oceanogr 30:102-110

Smith KL Jr, Carlucca AF, Williams PM, Henrichs SM, Baldwin RJ, Graven DB (1986) Zooplankton and bacterioplankton of an abyssal benthic boundary layer: in situ rates of metabolism. Oceanol Acta 9:47-55

Steedman HF (ed) (1976) General and applied data on formaldehyde fixation and preservation of marine zooplankton. Zooplankton fixation and preservation. UNESCO Press, Paris, p 103-154

Stuart V, Pillar SC (1990) Diel grazing patterns of all ontogenetic stages of Euphausia lucens and in situ predation rates on copepods in the southern Benguela upwelling region. Mar Ecol Prog Ser 64:227-241

Thiel H (1983) Meiobenthos and nanobenthos of the deep sea. In: Rowe GT (ed) The sea, Vol 8. Wiley, New York, NY, p 167-230

Torres JJ, Belman BW, Childress JJ (1979) Oxygen consumption of midwater fishes as a function of depth of 
occurrence. Deep-Sea Res A 26:185-197

Tranter DJ (1962) Zooplankton abundance in Australasian waters. Aust J Mar Freshw Res 13:106-142

Tselepides A, Eleftheriou A (1992) South Aegean (Eastern Mediterranean) continental slope benthos: macroinfaunal-environmental relationships. In: Rowe GT, Pariente V (eds) Deep-sea food chains and the global carbon cycle. Kluwer Academic Publications, Dordecht, p 139-156

> Vanucci S, Dell'Anno A, Pusceddu A, Fabiano M, Lampitt R, Danovaro R (2001) Microbial assemblages associated to sinking particles in the Porcupine Abyssal Plain (NE Atlantic). Prog Oceanogr 50:105-121

Vinogradov ME (1962) Feeding of the deep sea zooplankton. Rapp PV Reun Cons Int Explor Mer 153:114-120

Vinogradov ME (1968) Vertical distribution of the oceanic

Editorial responsibility: Antonio Bode, A Coruña, Spain zooplankton. Akad Nauk SSSR, Inst Oceanol, Moscow (Transl Israel Progr Sci Transl, 1970, 1-339)

Weikert H, Trinkaus S (1990) Vertical mesozooplankton abundance and distribution in the deep eastern Mediterranean Sea SE of Crete. J Plankton Res 12:601-628

Wiebe PH, Ashjian CJ, Gallager SM, Davis CS, Lawson GL, Copley NJ (2004) Using a high-powered strobe light to increase the catch of Antarctic krill. Mar Biol 144: 493-502

Wishner KF, Gowing MM, Gelfman C (2000) Living in suboxia: ecology of an Arabian Sea oxygen minimum zone copepod. Limnol Oceanogr 45:1576-1593

> Yebra L, Almeida C, Hernández-León S (2005) Vertical distribution of zooplankton and active flux across an anticyclonic eddy in the Canary Island waters. Deep-Sea Res I 52:69-83

Submitted: May 16, 2011; Accepted: November 14, 2011 Proofs received from author(s): January 19, 2012 